\title{
Circuit managers as agents of school development and support: A conceptual analysis
}

\author{
Barber M Mafuwane \\ Mvuyazi Primary School, Bohlabela District \\ Mpumalanga Provincial Department of Education, South Africa \\ Email address: barber.6405@gmail.com \\ Victor J Pitsoe \\ Department of Educational Leadership and Management, \\ College of Education, University of South Africa \\ Email address: Pitsovj@unisa.ac.za
}

\section{Doi:10.5901/mjss.2014.v5n9p439}

\begin{abstract}
The intention of this article is to provide clarity into the almost untapped role that circuit managers have to play in providing development and support to schools under their control. A definition of what it means to be a Circuit Manager and the roles and responsibilities attached to this position are presented. These are then juxtaposed with the supposed new role that Circuit Managers have to play as school development and support officers. In pursuit of the new role that circuit managers have to play in providing development and support to schools, this article argues that Circuit Managers need to provide instructional leadership to the schools under their control.
\end{abstract}

Keywords: circuit manager(s), school development, support, instructional leadership.

\section{Introduction}

Globally, successful school leadership is an issue of current debate which has been increasingly seen as a key factor in efficient and effective schooling system. The current debate about school leadership is, however, often dominated by an overarching approach, namely, instructional leadership. It is conceivably apposite to commence this discourse by indicating that there is increasing evidence that instructional leadership makes a difference in schools. According to Lai and Cheung (2013:322), since its inception in the 1980s, the notion of instructional leadership has attracted a growing amount of research interest. Most importantly, instructional leadership as a public pedagogy of practice is in part an exercise of power and authority. Among others, it embraces the values of justice, democracy and accountability. On one hand, Lai and Cheung (2013:322) contend that reviews of the instructional leadership literature show that greatest research attention has been given to examining the relationship between instructional leadership behaviours or practices and student and school outcomes. Furthemore, Louis et al. (2011) note in a recent review of literature that instructional leadership is an idea that refuses to go away, although it has been poorly defined since it was first introduced in the 1970s.

It is noteworthy to indicate that accountability policies, decentralization requirements, and demographic shifts have affected the content and foci of leadership preparation programmes in many countries (Ylimaki \& Jacobson, 2012:8). Notwithstanding the fact that instructional leadership was historically posed as a bureaucratic proposition for school improvement (Purinton 2013:280), it has been described as the glue that binds together school-wide goals, teacher needs and student learning (Bays \& Crockett, 2007). For Hargreaves and Fink (2006), powerful instructional leadership involves more than just a generic focus on instruction. A significant number on recent studies (Neumerski, 2013; Sofo et al., 2013; Purinton, 2013; Lai \& Cheung, 2013; Urick \& Bowers 2013; Hallinger \& Lee 2012) on instructional leadership emphasize the development of improved learning environments for teachers, focusing on the ability of principals to stimulate teachers' innovative behaviours rather than on their direct support. In spite of the abundance of studies on instructional leadership, very few, if any, have attempted to explore the role of Circuit Managers with regard to school development and support using the lens of instructional leadership.

Against this background, this article argues that if Circuit Managers were accountable for the performance of the schools under their control, then they have or at least should have a role to play in the development and support of their 
teachers. More often than not, Circuit Managers are in constant contact with school principals during service meetings and other workshops and seminars but they seldom meet teachers to discuss matters of development and support. Our point in this article is therefore that Circuit Managers should take a proactive role and provide programmes for the development and support of all staff in their circuits with a view to improve learner performance. Flowing from a recently completed doctoral study, Mafuwane (2011) examined the contribution of instructional leadership to learner performance and concluded that the Department of Education should empower principals with appropriate skills that will enable them to empower their staff. In this article, we pursue the same line of thinking by emphasizing that Circuit Managers should be more empowered with skills to be able to venture into the terrain of developing and supporting all development initiatives in their schools.

Circuit Managers play a pivotal role in school development and support - they have a strong role to play in forming school cultures that encourage change. Among others, within the framework of instructional leadership, Circuit Managers should be engaged with supervision, coaching, staff development, and modelling, designed to influence principals' thinking and practice. Central to this article is the assumption that in order to become effective instructional leaders, circuit managers should be more knowledgeable about and be involved in their schools' instructional practices than they had been in the past. Within this context, if substantial progress is to be made in school development and support, it is essential to rethink and explore the leadership role of Circuit Managers through the lens of instructional leadership theory. In this article; (1) we conceptualise instructional leadership, (2) explore the trends, challenges and prospects of instructional leadership, and (3) propose a shift towards instructional leadership in school development and support.

\section{Conceptualising Instructional Leadership}

While there is no one agreed-upon definition of instructional leadership (Urick \& Bowers 2013:507), the point to begin with is to acknowledge that instructional leadership differs from other models of leadership in that it focuses on how principals and teachers improve teaching and learning. However, Blase and Blase $(1999,350-1)$ write that instructional leadership is often defined as a blend of integrated tasks (supervision, staff, group and curriculum development, planning, organising, facilitating change, motivating staff and action research), and a myriad of approaches were identified democratic, collaborative, human resource-based, developmental, transformational) as well as new emerging approaches that focused on equity, reflection and growth. It is important to understand that instructional leaders focus on school goals, the curriculum, instruction, and the school environment (Stewart, 2006:4). This construct emerged during the 1980s as a branch of the effective schools research (Xie \& Shen, 2013; Neumerski, 2013; Purinton 2013, Lai \& Cheung, 2013; Townsend et al., 2013; Cheng-Yong, 2012; Sofo et al., 2012; Çalik et al., 2012; Ylimaki \& Jacobson, 2012 Hallinger \& Lee 2012); Goff et al., 2012 Klar, 2012; Lee, 2012). It focused on the manner in which leadership improved educational outcomes and also on the role of the principal to influence teachers on their teaching and learning practices as the teachers engaged in helping learners to learn.

As Gurr, Drysdale and Mulford (2006) observe, instructional leadership has its origins in the $19^{\text {th }}$ century under the inspection system that existed in North America, England, and Australia. It rose to prominence again in the United States in the 1970s when the instruction dimension of the role of the principal was emphasized (Townsend et al., 2013; Cheng-Yong, 2012; Neumerski, 2013; Purinton 2013, Lai \& Cheung, 2013; Townsend et al., 2013; Cheng-Yong, 2012; Sofo et al., 2012; Çalik et al., 2012; Ylimaki \& Jacobson, 2012 Goff et al., 2012 Klar, 2012 Lee, 2012; Hallinger \& Lee, 2012). From the 1960s onwards, the definitions of this concept ranged from any activity in which the principal engaged in order to improve instruction, to certain types of activities or actions such as classroom observation (Gorton as cited by Gurr et.al, 2006). Some scholars (Cheng-Yong, 2012:184; Smith \& Andrews as cited by Enueme \& Egwunyenga, 2008:13) view instructional leadership as a blend of supervision, staff development, and curriculum development that facilitates school improvement.

For Masumoto and Brown-Welty (2009:3), instructional leadership focuses on the principal's influence on learner performance: how the principal positively affects teachers, the outcome of teaching, and raises learner performance. Research (Leithwood, Louis, Anderson, and Wahlstron, 2004; Waters, Marzano \& MacNulty, 2003) emphasizes the role of the principal as an instructional leader, in setting directions, developing the educators on matters of instruction, and making the school work. The $20^{\text {th }}$ and $21^{\text {st }}$ century views of instructional leadership emphasize that instructional leadership encompasses those actions that a principal takes or delegates to others, in order to promote growth in learner performance and, according to Wildy and Dimmock (1993:144), the principal must be able to define the purpose of schooling, set school-wide goals and put in place strategies to achieve those goals; provide the educators and learners with all the resources necessary for effective learning to occur; supervise and evaluate teachers in line with the performance of their learners; initiate and co-ordinate in-house teacher development programmes, and create and 
nurture collegial relationships with and among teachers.

In concurring with the views of the scholars cited above and their assumptions about instructional leadership, Elmore $(2000 ; 2005)$ and Daresh (2007) share the view that all primary activities undertaken by principals should be tightly coupled to the core technology of schooling, which is teaching and learning. This view implies that a principal's role is instructional leadership and as such, the principals must direct changes to teaching and learning. Distributing leadership roles to others in the school (teachers, heads of departments, and deputy principals) further explains the role of the principal as an instructional leader and also his/her perceptions of leadership. Based on the above views, Daresh (2007) and Elmore (2000) proposed a definition of instructional leadership that would differentiate it from school leadership in general. They suggest that instructional leadership is a type of leadership that should guide and direct instructional improvement associated with learner performance. Hallinger (2003) conceptualizes instructional leadership by proposing three dimensions: defining the school's mission, managing the instructional programme, and promoting a school-learning climate. Dimmock (1995:295) indicates that instructional leadership is based primarily on a strong technical knowledge of teaching and learning and also on curriculum design, development and evaluation. This article sets out to explore the extent to which Circuit Managers' enactment of the above-mentioned dimensions contributes to learner performance.

\section{Trends, Challenges and Prospects of Instructional Leadership}

We start from the plain scrutiny that while the concept of instructional leadership started gaining prominence during the 1970s in the developed countries of the world as indicated earlier in this article, it started gaining prominence recently in South Africa. The linking of the practice of instructional leadership with the principal is well known and documented and it is in essence the dominant trend in education practice in schools today. While some education practitioners find it strange and impossible for a school principal to execute this role, principals in developed parts of the world find it to be the way to go. The view held by this article is that the enactment of an instructional leadership role by Circuit Managers will go a long way into inspiring principals to do the same.

\subsection{Instructional leadership and the supportive role of circuit managers}

The concept Circuit Manager is broadly used. According to the DoBE (2011:12), a Circuit Manager is the head of a Circuit Office. He/she executes prescribed functions using powers delegated by the District Director. However, the names given to these officials differ from one province to another, as indicated in the table below:

Table 1: Names given to heads of circuits according to provinces

\begin{tabular}{|l|l|}
\hline Province & Name \\
\hline 1. Eastern Cape, Limpopo; Mpumalanga & Circuit Manager \\
\hline 2. Free State & School Management Governance and Development (SMGD) \\
\hline 3. Gauteng & Institutional Development and Support Officer (ISDO) \\
\hline 4. North West & Institutional Support Coordinator (ISC) \\
\hline 5. Western Cape & Institutional Management and Governance (IMG) \\
\hline
\end{tabular}

It is noteworthy to indicate that for the purpose of this article, the concept of Circuit Manager, as commonly used in the Mpumalanga Province will be used. According to the National Professional Teachers Organization of South Africa (NAPTOSA) and the Northern Cape Department of Education (2010), the following key performance areas are attached to the Circuit Manager: monitoring curriculum delivery, by bringing all curriculum challenges picked up at the schools to the attention of the curriculum advisors; staff development; office administration; providing administration services to schools; providing management support to schools by resolving all management problems encountered by the school principals and managing all the recovery plans in the circuit.

From the key performance areas indicated above, staff development and management support feature prominently and will therefore be the focus of this article. It is important at this point to indicate what the two concepts mean. Staff development is a systematic approach to change at the school level designed to guide and focus a school towards the achievement of its mission, which is enhanced student learning. Staff development and the direction that it has to take will always take the uniqueness of each school into consideration. Due to this uniqueness, assisting each school to develop, implement and sustain a staff development plan will require more energy and versatility from those concerned and in this 
case, the Circuit Mmanager.

Staff development and support are among the many functions of an instructional leader and the performance of these functions by circuit managers qualifies them to be instructional leaders. Furthermore, the enactment of the role of an instructional leader by the Circuit Managers emphasises the complex and dynamic nature of this position.

\subsection{Implications of instructional leadership in school development and support}

Caldwell (2002) and Hallinger (2002) indicate that schools as organizations have become less in need of control and more in need of support and capacity development. This view implies that schools need the support of the Department of Education in their endeavour to improve learner performance. The tiers of the department which is closest to the schools and well placed to provide the necessary support are the circuit and district offices. Togneri and Anderson (2003:23); Anderson (2003:8-11) and the Centre for Comprehensive School Reform (2006:1) provide valuable information with regard to the role of circuits, districts offices and officials in providing support and school development initiatives which in turn contribute to the improvement of school performance. In addition to the schools' own vision, accountability systems and curricular goals, the district must also set a clear vision, coherent curricular targets and accountability systems and teach the principals and teachers how to use these support initiatives to improve instruction for individual learners. Districts must move beyond the traditional one-time workshop approach to professional development that puts in place coherent, district-organized strategies to improve instruction.

Districts must also ensure that there is a connection between the school-based professional development activities and district level professional development. The goals of the district regarding learner performance should be directly connected to the school-level practices and the needs of the learners. Districts should increase instructional leadership by building well-trained cadres of instructional experts among the teacher and principal corps. This view emphasizes the fact that principals are not expected to lead alone and teachers are also not expected to work in isolation. Fostering networks of instructionally proficient principals and teacher leaders (e.g. content specialists and mentor teachers), districts may be able to increase their capacity to improve instructional practice. Novice teachers need mentoring and the district has the obligation to provide support systems for these new teachers. In order for the district to provide the necessary support to schools, strategic allocation of financial resources is imperative. Anderson (2003:11) refers to this aspect as "investment in instructional leadership development at the school and district levels" and further adds that one of the hallmarks of districts that have succeeded in moving from low to high performing in terms of learner performance is an intensive longterm investment in developing instructional leadership capacity at the school as well as at the district level.

Drawing from the above information, the support of the Circuit Managers is therefore important for the holistic development of schools. Newmann, King and Youngs (2001) and Schmoker and Marzano (1999) emphasize the concepts of programme coherence, alignment and coordination of the curriculum. They argue against schools and districts/circuits "doing their own thing". Their contention is that unrelated and unfocused school development programmes may have a negative impact on the holistic development of the school. The Circuit Managers should therefore provide support systems and school development models which prepare principals and teachers to be able to align and coordinate their school development plans for the holistic development of their schools.

\section{Towards Instructional Leadership in School Development and Support}

The level of accountability that Circuit Managers currently have with regard to the performance of the schools under their control is incompatible with the extent to which they provide development and support to their schools. The enactment of instructional leadership demands more than just serving as a conduit of information between parties. More often than not, Circuit Managers serve as messengers between schools and the district offices and this does not conform to the purpose of instructional leadership which is to improve learner performance.

Circuit Managers, in their quest to improve the performance of their schools, should engage in instructional leadership and school development and support activities such as: providing frequent, appropriate and school-wide development and support activities; defining and communicating a shared vision and goals for the circuit; setting up monitoring systems and providing feedback to all schools on the impact of the development and support activities provided and expect the schools to do the same. Above all, Circuit Managers should see and portray themselves as institutional development and support officers to their schools than to be managers of the status quo. In many cases, Circuit Managers do not have their own visions for their circuits which would direct the visions of the schools in their circuits. This implies that the Circuit Manager is always caught between contradicting visions, that is, the vision of the province and the myriad of different visions of many schools in the circuit. It is therefore important that (as indicated 
above) each circuit adopts a vision that would inform the visions of the schools in that circuit. This approach will enable the Circuit Manager to provide appropriate support and development towards the fulfilment of the circuit vision.

In summing up, schools need a concerted leadership effort by the school principals and their Circuit Managers. For us, a Circuit Manager who "walks the factory floor" will more likely succeed in improving the performance of the schools under his control than one who gives a lecture on how to walk the factory floor. The success of circuit managers as instructional leaders will depend more on their assumption of this new role of instructional leadership than to serve as messengers of the district office. A Circuit Manager, who plans together with the principals in the circuit, becomes the custodian of the plan and from time to time evaluates the plan, is more likely to succeed that one who expects the principals to plan for each academic year. The view that "a circuit that plans together wins together" holds true in this regard.

\section{Conclusion}

This article ventured into a new and untapped terrain that proposes a new role for Circuit Managers, the role of instructional leadership. The leadership literature does not say anything about Circuit MManagers engaging is in this role and this makes this article to be unique and to contribute in the academic debate that may arise to test the ability of Circuit Managers to enact this role. The authors hold the view that Circuit Managers have an instructional leadership role to play in order to provide development and support to their schools. Planning for each academic year together, having a common vision for all the schools in the circuit and continuously communicating this view to all schools will ensure that all the schools succeed together.

\section{References}

Anderson, S.E. (2003). The School District Role in Educational Change: A Review of Literature. International Centre for Educational Change. Ontario Institute for Studies in Education.

Bays, D.A.; and Crockett, J.B. (2007). Investigating instructional leadership for special education. Exceptionality, 15(3): 143 - 161.

Blase, J., and J. Blase. 1999. Principals' instructional leadership and teacher development: Teachers' perspectives. Educational Administration Quarterly, 35(3): 349-378.

Caldwell, B.J. (2002). A Blueprint for successful leadership in an era of globalization in learning. In Hallinger, P. (Ed.). Reshaping the Landscape of School Leadership Development: A Global Perspective. Lisse, Netherlands: Swets and Zeitlinger.

Cheng-Yong, T. (2012) Instructional leadership: toward a contextualised knowledge creation Model. School Leadership \& Management: Formerly School Organisation, 32(2): 183-194.

Çalik, T., Sezgin, F., Kavgaci, H. \& Kilinç, A.Ç. (2012). Examination of Relationships between Instructionalleadership of School Principals and Self-Efficacy of Teachers and Collective Teacher Efficacy. Educational Sciences: Theory \& Practice, 12(4): 24982504.

Dimmock, C. (1999). Principals and School Restructuring: Conceptualizing Challenges as Dilemmas. Journal of Educational Administration, Vol. 37(5): 441-462.

Elmore, R. (2000). Building a New Structure for School Leadership. Washington, DC, The Albert Shanker Institute.

Enueme, C.P. \& Egwunyenga, E.J. (2008). Principals' Instructional Leadership Roles and Effect on Teachers' Job Performance: A Case Study of Secondary Schools in Asaba Metropolis, Delta State, Nigeria. Journal of Social Sciences, 16(1): 13-17.

Goff, PT., Mavrogordato, M. \& Goldring, E. (2012) Instructional Leadership in Charter Schools: Is There an Organizational Effect or Are Leadership Practices the Result of Faculty Characteristics and Preferences?, Leadership and Policy in Schools, 11(1): 1-25.

Gurr, D., Drysdale, L. \& Mulford, B. (2006). Instructional Leadership in Three Australian Schools. Centre for Organizational Learning and Leadership, University of Melbourne

Hallinger, P. (2002). The Emergence of School Leadership in an Era of Globalisation: 1980 - 2002 in Hallinger, P. (2003). Reshaping the Landscape of Leadership Development.

Hallinger, P. (2003). The Emergence of School Leadership Development in an Era of Globalization: 1980 - 2002. In Hallinger, P. (2003). Reshaping the Landscape of School Leadership Development.

Hallinger, P \& Lee, M. (2012) A Global Study of the Practice and Impact of Distributed Instructional Leadership in International Baccalaureate (IB) Schools, Leadership and Policy in Schools, 11(4): 477-495.

Hargreaves, A., \& Fink, D. (2006). Sustainable leadership. San Francisco: Jossey-Bass.

Klar H.W. (2012) Fostering department chair instructional leadership capacity: laying the groundwork for distributed instructional leadership. International Journal of Leadership in Education: Theory and Practice, 15:2, 175-197.

Lai, E. \& Cheung, D. (2013). Implementing a new senior secondary curriculum in Hong Kong: instructional leadership practices and qualities of school principals. School Leadership \& Management: Formerly School Organisation, 339(4): 322-353.

Lee, M. (2012) Contrasting effects of instructional leadership practices on student learning in a high accountability context Journal of Educational Administration 50(5): 586-611.

Leithwood, K., Seashore Louis, K., Anderson, S.A. \& Wahlstrom, K. (2004). How leadership influences student learning. New York: 
Wallace Foundation.

Mafuwane, B.M. (2011). Contribution of Instructional Leadership to Learner performance. Unpublished Doctoral Thesis. University of Pretoria.

Masumoto, M. \& Brown-Welty, S. (2009). Case Study of Leadership Practices and School-Community Interrelationships in HighPerforming. Education, 24(1):1-18.

Neumerski, C.M. (2013). Rethinking Instructional Leadership, a Review: What Do We Know About Principal, Teacher, and Coach Instructional Leadership, and Where Should We Go From Here? Educational Administration Quarterly, 49(2): 310-347.

Newmann. F.M., King, M.B. \& Youngs, P. (2001). Professional development that addresses school capacity: Lesson from urban elementary schools. Paper presented at the annual meeting of the American Educational Research Association, New Orleans, LA.

Purinton, T. (2013) Is instructional leadership possible? What leadership in other knowledge professions tells us about contemporary constructs of school leadership, International Journal of Leadership in Education: Theory and Practice, 16(3): 279-300.

Schmoker, M. \& Marzano, R.J. (1999). Realizing the promise of standards-based education. Educational Leadership, 56(6): 17-21.

Sofo, F., Fitzgerald, R. \& Jawas, U. (2012). Instructional leadership in Indonesian school reform: overcoming the problems to move forward. School Leadership \& Management, 32(5): 503-522.

The Centre for Comprehensive School Reform and Improvement (2005). Newsletter: Redefining professional development. Retrieved from http://www.centreforcsri.org

The Centre for Comprehensive School Reform and Improvement. Newsletter: Redefining professional development. Retrieved from http://www.centreforcsri.org

Townsend, T., Acker-Hocevar, M., Ballenger, J. \& Place, W. (2013) Voices From the Field: What Have We Learned About Instructional Leadership? Leadership and Policy in Schools, 12(1): 12-40.

Urick A \& Bowers AJ (2013) What are the Different Types of Principals Across the United States? A Latent Class Analysis of Principal Perception of Leadership. Educational Administration Quartely XX(X) http://eaq.sagepub.com/content/early/2013/06/19/001316 1X13489019

Waters, T., Marzano, R.J. \& McNulty, B. (2003). Balanced Leadership: What 30 years of research tells us about the effect of leadership on student achievement. McRel.

Wildy, H. \& Dimmock, C. (1993) Instructional leadership in primary and secondary schools in Western Australia. Journal of Educational Administration, Vol. 31(21), 43-61.

Stewart, J. (2006). Transformational leadership: An Evolving Concept Examined through the works of Burns, Bass, Avolio \& Leithwood. Canadian Journal of Educational Administration and Policy, Issue 54, June 26, 2006.

Xie, D. \& Shen, J. (2013) Teacher leadership at different school levels: findings and implications from the 2003-04 Schools and Staffing Survey in US public schools. International Journal of Leadership in Education: Theory and Practice, 16(3): 327-348.

Ylimaki, R. \& Jacobson, S. (2012). School leadership practice and preparation: comparative perspectives on organizational learning $(\mathrm{OL})$, instructional leadership (IL) and culturally responsive practices (CRP). Journal of Educational Administration, 51(1): 6-23. 